\title{
Wacana Khitan Perempuan Di Masyarakat Desa (Studi di Masyarakat Desa Pager, Kecamatan Purwosari, Kabupaten Pasuruan)
}

\author{
Ach. Nashichuddin
}

Penulis adalah Dosen Universilas Islam negeri (UIN) Malang

\section{ABSTRACT}

This research aims to describe a discourse of female circumcision in desa Pager, kecamatan Purwosari, kabupaten Pasuruan. There are two discourses that are described in this research; discourse of fiqih text that consists of books written by Moslem scholar of Syafi'iyah and discourse of social context in the village. Election to books written by Moslem scholar of Syafi' iyah is based on the reality that most of societies in Pager are traditional Moslem group who follow to Syafi'iyah School. Then, those two discourses are compared to find equation and difference. In this research is found, that no all fiqih books, which are spread over in society explain about female circumcision. The explanation is only found in advanced fiqih books that seldom be touched by civil society. In fiqih books expressed that majority of Moslem scholar see that female circumcision is religious obligatory either for men and woman. For a while other minority Moslem scholar see that it is obliged to men and recommended to woman. Suggested procedure is cutting part of the clitoral foreskin above the vagina, the fewer is assumed better. While in social context in Pager, female circumcision is not experienced again although some of them still assume that female circumcision is obligatory or recommended. In 1960s, female circumcision was entrenched among society in Pager in which a female dukun of female circumcision was found. The procedure is as those that was suggested in fiqih books. After the female dukun 
died, this practice was continued by dukun bayi with different procedure, that is only a symbolic gesture. At that time, social attention to female circumcision became loose. When the childbirth care was taken over by midwife, this tradition is lost without feeling of committing sin, because they assume that female circumcision is a tradition of ancient society, which is not related to religious teaching. Here it has been clear, that at the moment, there is a significant difference between the fiqih text and the social context in Pager in explaining the meaning of female circumcision practice. There are three factors that cause the difference; the social and cultural change in the society, the change of thought system in the society, and the lack of knowledge regarding the fiqih text that explains female circumcision.

\section{A. Pendahuluan}

Beberapa tahun terakhir ini, tradisi khitan perempuan mulai marak diperbincangkan di kalangan masyarakat Indonesia. Hal ini ditandai dengan banyaknya penelitian yang bertemakan khitan perempuan, mulai dari penelitian untuk mendeskripsikan tradisi ini di daerah tertentu hingga penelitian literatur untuk mengkaji kefalidan hadits yang dijadikan dasar hukum khitan perempuan. Bahkan pada pertengahan tahun 2003 prakten ini diangkat sebagai laporan utama di sebuah majalah mingguan nasional. "Gugatan" terhadap tradisi ini tidak hanya dilontarkan oleh para aktifis feminis dengan bersandar pada alasan hak-hak asasi manusia, tetapi juga dilontarkan oleh para agamawan muslim yang mempertanyakan kembali dasar hukum tradisi khitan perempuan.

Namun tidak dapatdielakkan bahwa beberapa penelitian yang telah dilakukan di beberapa daerah di Indonesia menunjukkan bahwa motivasi agama masih menjadi alasan utama dilakukannya praktek khitan perempuan selain untuk meneruskan tradisi leluhur. Seperti penelitian yang dilakukan Andree Feillard dan Lies Marcos pada 1997-1998. Mereka menemukan bahwa khitan perempuan telah dilakuan oleh hampir seluruh umat Islam di nusantara secara turun-temurun bahkan cenderung dijadikan tanda pengislaman seseorang.' Temuan lain juga menyebutkan bahwa khitan perempuan telah dilakukan secaraturun-temurun di Wana Lampung Timur. Alasan utama mereka melakukan praktek khitan perempuan adalah untuk meneruskan tradisi nenek moyang dan menjalankan perintah agama. ${ }^{2}$ Penelitian yang sama juga dilakukan di Yogyakarta dan Madura dengan temuan bahwa 79,3

Ulul Albab, Vol. 4 No. 1, 2003 
persen responden di Madura melakuan khitan untuk menjalankan perintah agama. Sedangkan di Yogyakarta hanya 31 persen responden melakukan khitan juga karena alasan agama. ${ }^{3}$

Dalam tulisan ini, akan dipaparkan hasil penelitian tentang wacana khitan perempuan di desa Pager kecamatan Purwosari kabupaten Pasuruan. Ada dua wacana yang dibahas dalam penelitian ini, yaitu wacana khitan perempuan dalam teks. fiqih yang terdapat dalam kitab-kitab fiqih dan wacana khitan perempuan dalam konteks masyarakat desa Pager. Sealanjutnya, dua wacana tersebut dibandingkan hingga akan ditemukan perbedaan dan persamaannya. Perbandingan di sini lebih ditekankan pada upaya melihat apakah wacana yang ada dalam teks fiqih dipatuhi oleh masyarakat desa Pager yang mayoritas penduduknya adalah kelompok muslim tradisional. Dan pada akhir tulisan ini akan dijelaskan penyebabpenyebab yang paling dominan yang menyebabkan terjadinya perbedaan tersebut.

\section{B. Deskribsi Khitan Perempuan}

Secara harfiyah kata "khitan" berasal dari bahasa Arab "khatn" artinya menotong. Kata khatn sendiri berarti khitan bagi laki-laki, sedangkan khitan bagi perempuan adalah khafdh. ${ }^{`}$ Namun demikian, ada yang berpendapat bahwa istilah khatn berlaku baik untuk laki-laki maupun perempuan. Hal ini berdasar pada makna asli dari kata "khitan" dalam bahasa Arab adalah bagaian yang dipotong dari kemaluan laki-laki atau perempuan. ${ }^{5}$ Maka dari itu apabila didefinisikan secara lengkap, khitan laki-laki adalah pemotongan kulit yang menutupi kasyafah (kepala penis) dan khitan perempuan adalah pemotongan bagian paling atas (klentit) dari faraj (kemaluan) perempuan, (tepatnya) di atas tempat masuknya penis yang berbentuk seperti biji atau seperti genjer ayam jago. ${ }^{6}$

Sementara itu di kalangan masyarakat Indonesiaterdapatbanyak istilah untuk menyebut khitan perempuan. Ada yang menyebutnya kattang (di Makasas), katta (di Bugis), tetesan (di Yogyakarta), bersoenat rasoel (di Batu Sangkar) dan berchatan (di Selat Panjang). Tetapi pada umumnya masyarakat Indonesia menyebutnya soenat yang berarti menjalankan tradisi Nabi Muhammad SAW. Sebab seperti disebutkan dalam sejarah bahwa, Nabi Muhammad SAW dilahirkan dalam keadaan dikhitan. ${ }^{7}$ Ada juga dikalangan masyarakat Jawa yang menyebutnya

Ulul Albab, Vol. 4 No. 1, 2003 
selam atau nyelamake yang berarti proses mengislamkan seseorang, atau dengan kata lain orang akan dianggap telah menjadi seorang muslim yang sempurna dan berhäk menghadiri undangan selamatan apabila telah dikhitan. ${ }^{8}$

\section{Wacana Khitan Perempuan dalam Teks Fiqih}

Teks fiqih dalam tulisan ini lebih ditujukan kepada kitab-kitab fiqih karya para ulama Syafi' 'iyah. Pengkhususan ini didasarkan pada kenyataan di lapangan bahwa masyarakat desa Pager mayoritas bermadzhab Syafi'iyah, sehingga penelitian tetang teks fiqih juga akan difokuskan kepada kitab-kitab Syafi'iyah.

Ditinjau dari segi kedalaman pembahasannya, kitab-kitab fiqih Syafi' iyah bisa digolongkan menjadi dua kelompok, yaitu kitab-kitab pemula yang pembahasannya sangat global dan kitab-kitab lanjut yang pembahasannya lebih mendetail. Umumnya, pengajaran kitab-kitab pemula dilakukan dengan metode sorogan hal mana murid-murid dibimbing membaca kata-perkata sekaligus dengan maknanya. Dalam pengajaran kitab-kitab pemula murid-murid ini tidak disyaratkan menguasai tata bahasa maupun kosa kata bahasa Arab. Sedangkan kitab-kitab lanjut hanya dipelajari oleh murid-murid yang sudah menguasai tata bahasa dan kosa kata bahasa Arab. Sehingga dalam proses pengajarannya, murid-murid hanya mendengarkan bacaan ustadznya atau murid-murid yang membacanya dan ustadz hanya mengoreksi bacaan tersebut kemudian memberi penjelasan secukupnya.

Setelah melakukan penelaahan terhadap kitab-kitab penula khüusnya yang diajarkan di madrasah diniyah di desa Pager, tidak ditemukan pembahasan tentang khitan, baik laki-laki maupun perempuan. Pembahasan tentang khitan perempuan ternyata hanya ditemukan dalam kitab-kitab lanjut seperti fath al mu 'în oleh syekh Zainuddin bin Abdul Aziz al Malibary, I'anah al Thâlibîn oleh Muhammad Shatha al Dimyathy, hawâshy al sharwâny oleh Al Sharwâny dan Qosim Al-Ibady, Mughiny al Muhtâj oleh Syekh Muhammad Al Khatib al Sharbiny, dan Is 'âd al rafiq oleh Syekh Muhammad bin Salim bin Sa'id.

Dalam kitab-kitab tersebut, penibahasan khitan perempuan menjadi satu rangkaian dengan pembahasan khitan laki-laki yang merupakan sub pokok bahasan dari bab "hukum melukai badan" yang termasuk di dalamnya hukum menindik 
bagian tubuh. Kecuali dalam kitab Is 'âd al-rafíq, pembahasan khitan perempuan disinggung|dalam pembahasan ma'shiyat al-farj(maksiat yang dilakukan kemaluan).

"Salah satu maksiat kemaluan adalah meninggalkan khitan setelah mencapai akil baligh, baik bagi laki-laki maupun perempuan, yaitu dengan menotong kulup bagi laki-laki dan memotong kelentit bagi perempuan." 9

Walaupun letak pembahasannya berbeda tetapi inasalah pokoknya sama, yaitu khitan harus dilakukan baik bagi laki-laki maupun perempuan.

Secara ringkas sistematika pembahasannya dapat diuraikan sebagai berikut;

\section{Penegasan Hukum Khitan.}

Pembahasan dimulai dengan penegasan hukumnya khitan bagi laki-laki dan perempuan menurut jumhur (mayoritas) ulama yang wajib bagi keduanya disertai dalil dari Al-Qur'an atau Al-Sunnah. Ayat Al-Qur'an yang dikutip adalah QS. AnNahl ayat 123 yang berisi tentang anjuran mengikuti agama Ibrahim yang salah satunya adalah khitan. Sedangkan Al-Sunnah yang dikutip adalah hadits dari Ummu 'Athiyah. Setelah itu baru dipaparkan pendapat sebagian kecil ulama yang menghukumi wajib bagi laki-laki dan sunnah bagi perempuan.

\section{Definisi dan Batasan Khitan Perempuan}

Redaksi definisi yang tertuang dalam kitab-kitab tersebut relatif sama baik dari sisi batasannya maupun bahasa yang digunakan. Seperti dalam kitab I'anah al-thâlibîn disebutkan;

"Bagi perempuan adalah memotong gabian organ yang terletak di atas kemaluan tempat jalannya kencing yang menyerupai jengger ayam yang disebut kelentit."

Dalam definisi di atas nampak jelas bahwa dalam khitan perempuan harus terjadi pemotongan walaupun sedikit. Sedangkan dalam prakteknya lebih sedikit adalah lebih baik dengan didasarkan pada hadits yang diriwayatkan oleh Abu Dawud, sesungguhnya Rasulullah bersabda; "potonglah sedikit dan janganlah

Ulul Albab, Vol. 4 No. 1, 2003 
engkau merusaknya, karena ia dapat membuat wajah menjadi cerah dan dapat membuat suami lebih senang."

\section{Waktu Pelaksanaan Khitan Perempuan}

Pelaksanaan khitan, baik laki-laki maupun perempuan, disunnahkan pada usia tujuh hari atau empat puluh hari. Apabila terlanjur belum dikhitan, sebaiknya diselenggarakan ketika berumur tujuh tahun, hal ini mengingat pada usia itu anak sudah mulai dianjurkan mendirikan shalat. Pada khitan laki-laki penyelenggaraannya disunnahkan dengan acara walimah (pesta), dan sebaliknya bagi perempuan penyelenggaraannya harus disembunyikan ${ }^{12}$.

\section{Wacana Khitan Perempuan dalam Konteks Masyarakat Desa Pager}

Dalam konteks masyarakat desa Pager, tradisi khitan perempuan dimaknai secara beragam. Ada yang memahaminya sebagai ajaran agama yang menjadi religious identity. Menurut pemahaman sebagian masyarakat desa Pager yang masih awam terhadap ajaran agama Islam, khitan merupakan salah satu ciri dari orang Islam. Oleh sebab itu khitan harus dilakukan baik oleh laki-laki maupun perempuan. Hal ini seperti diungkapkan oleh salah seorang dukun bayi;

“... sunat niku hukume wajib kangge tiang jaler lan tiang estri. Nek wonten tiang engkang mboten disunat niku arane kapir sanes tiang Islam. Mangkane yen kulo nolong bayi wadon langsung kulo sunat..."

(“...sunat itu hukumnya wajib bagi laki-laki maupun perempuan. kalau ada orang yang tidak dikhitan berarti kafir bukan orang Islam. Makanya, kalau saya menolong bayi perempuan langsung saya khitan...)

Pemaknaan khitan perempuan sebagai religious identity juga dijumpai pada tahun 1060an, ketika khitan perempuan masih membudaya di masyarakat desa Pager hal mana masih ada seorang dukun khitan perempuan. Pemaknaan ini tidak hanya melekat pada orang tua, tetapi justru belih melekat pada anak-anak. Bahkan mereka akan merasa malu bila tidak dikhitan seperti yang dijelaskan seorang sesepuh di desa Pager; 
“...riyen sek jamane tasek wonten dukun sunat estri, sedoyo lare estri disunat. biasane nek mantun rioyo kupat dukune marani teng griyane tiang-tiang trus nakoi senten seng dereng sunat. Nek wonten lare pun ageng tapi dereng disunat, biasane diilokno koyok wong cino. Mangkane seringe sunat niku boten sangkeng perintahe wong tuwo utowo guru ngaji, tapi sangking are'e dewe sing isin diilokno wong cino"

(...dulu ketika masih ada dukun khitan perempuan, semua anak perempuan dikhitan. Biasanya setelah hari raya ketupat dukun tersebut mendatangi rumahrumah penduduk dan menanyakan siapa yang belum dikhitan. Kalau ada anak sudah besar tapi belum disunat, biasanya diolok-olok seperti orang Cina. Makanya, kebanyakan khitan yang mereka lakukan bukan karena diperintah orang tuanya atau guru ngajinya, tetapi kareana dia malu dijuluki orang Cina..")

Julukan sebagai "orang Cina" bisa diartikan dua hal; pertama, orang Cina adalah simbol dari orang yang tidak beragama Islam. Dengan kata lain, khitan merupakan identitas orang Islam yang membedakan mereka dengan orang yang tidak beragama Islam. Oleh sebab itu, anak yang tidak dikhitan dianggap belum menjadi muslim. Kedua, julukan itu bisa diartikan sebagai sanksi sosial yang diberikan oleh anak-anak kepada temannya yang belum dikhitan. Perasaan malu karena dijuluki sebagai "orang Cina" bisa mendorong mereka untuk dikhitan walaupun sudah menghinjak usia menjelang dewasa. Kondisi inilah yang lebih banyak berperan dalam keberlangsungan khitan perempuan dibandingkan dengan adanya anjuran dari tokoh agama ataupun orang tua.

Pada kelompok masyarakat yang lebih mengerti tentang ajaran Agama, khitan perempuan dipahami sebagai praktek yang sunnah dilakukan, bila dilakukan akan mendapat pahala dan bila ditinggalkan tidak ada ancaman dosa. Menurut mereka, praktek khitan perempuan merupakan sunnah Rasulullah yang pasti ada hikmah yang bermanfaat bagi manusia. Salah satu hikmahnya adalah upaya menjaga kebersihan walaupun dalam prakteknya hanya dilakukan secara simbolik tanpa memotong dan tanpa keluar darah. Hal ini seperti dituturkan oleh salah seorang tokoh agama yang bertempat tinggal di dusun Pager Lor;

“...sunate tiang estri niku saget diibarataken perintah motong kuku wonten dino Jum'at. Motong kuku wonten dino Jum'at niku hukumesunnah senajan kukune wes jendek. Nek wes gak ono kuku seng dowo, supoyo tetep oleh sunnahe, cukup 
dikerek panggonan cukule kuku. Sonate tiang estri nggeh ngoten, senajan wes orah ono seng dipotong, cukup dikerek mawon..."

(“...sunatnya orang perempuan itu bisa diqiyaskan dengan memotong kuku pada hari Jum'at. Memotong kuku pada hari Jum'at adalah hukumnya sunnah walaupun kukunya sudah pendek. Kalau sudah tidak ada kuku yang panjang, supaya tetap dapat sunnahnya, cukup digosok tempat tumbuhnya kuku. Sunatnya orang perempuan juga seperti itu, walaupun tidak ada yang dipotong, cukup digosok saja (secara simbolik)..."

Sedangkan menurut sebagaian besar masyarakat desa Pager, khitan perempuan dimahami sebagai tradisi yang diwariskan secara turun-temurun. Sebagaimana disebutkan di atas bahwa, tradisi khitan perempuan adalah budaya masyarakat desa Pager pada tahun 1960an di saat masih ada dukun khusus khitan perempuan. Karena begitu membudaya, sehingga hampir semua anak perempuan di desa tersebut menjalani khitan.

Keberlangsungan khitan perempuan di desa Pager lebih didorong oleh keberadaan dukun khitan perempuan dibandingkan dengan adanya internalisasi nilai budaya dalam masyarakat atau atas anjuran para tokoh agama. Hal ini bisa dilihat dari nasib tradisi khitan perempuan pada saat ini yang sudah ditinggalkan oleh masyarakat desa Pager. Setelah dukun khitan perempuan meninggal dunia, tradisi ini hilang dengan sendirinya. Walaupun masih ada dukun bayi yang menjalankan praktek ini, tetapi lingkungan masyarakat sudah tidak menghiraukan keberlangsungannya, begitu pula para tokoh agama yang tidak pernah berfatwa untuk melanjutkan tradisi ini.

Mayoritas masyarakat desa Pager menganggap bahwa khitan perempuan adalah budaya masyarakat Jawa bukan ajaran agama. Pendapat ini didukung oleh beberapa tokoh masyarakat dan tokoh agama yang lain. Antara lain disampaikan oleh seorang informan yang juga mantan kepala desa pada tahun 1960an;

“...sunat tiang estri niku cuman tradisine tiang rien seng sak niki pun mbuten wonten male. Tradisi niki boten bedo kalian tradisi ritual lintune kados ritual copot udel, nggeh meniko selametan kanggeh nandai copote udele bayi. Rien tiang meriki tasek ngelampai ritual niki, carane masang godong pandan eri wonten ngajengi lawang lan gawe golekan kayu didele wonten ngandape turone bayi. Lajeng bayine digendong ngantos tengah wengi. Tradisi-tradisi kados meniko sak niki sampon

Ulul Albab, Vol. 4 No. 1, 2003 
mboten dịlampahi tiang meriki. Tiang meriki ngganggep yen sedoyo niku namun mitos engkang mbotem masuk akal, hinggo mboten terlalu penting ngelampahaken, termasuk tradisi sunat tiang estri.."

("...khitan perempuan hanyalah tradisi masyarakat kuno yang sekarang sudah tidak ada lagi. Tradisi ini tidak berbeda dengan tradisi Jawa lain seperti ritual "copot puser", yaitu upara selamatan untuk menandai copotnya puser seorang bayi. Dahulu masyarakat desa Pager masih melakukan ritual tersebut dengan memasang daun pandan berduri di depan pintu dan membuat golekan dari kayu yang diletakkan di bawah kolong tempat tidur bayi. Kemudian bayi yang bersangkutan harus digendong sampai lepas dini hari. Tradisi-tradisi seperti itu sekarang sudah tidak dilakukan oleh masyarakat desa Pager. Mereka menganggap bahwa semua itu hanya didasarkan pada mitos dan tidak masuk akal, sehingga tidak terlalu penting untuk dilakukan termasuk khitan perempuan...")

Informasi di atas juga dibenarkan oleh seorang tokoh agama yang domisili di dusun Baran. Ia beranggapan bahwa khitan perempuan adalah tradisi masyarakat di Afrika yang tidak ada kaitannya dengan ajaran agama. Jika ada masyarakat desa Pager yang menjalaninya, itu berarti mereka hanya meniru tradisi yang dilakukan oleh orang-orang di Afrika. Maka dari itu, ia berpendapat bahwa khitan perempuan bila ditinjau dari kaca mata agama hukumnya adalah mubah (boleh dilakukan tanpa ada pahala atau ancaman dosa), sebab dalam Al-Qur'an maupun As-Sunnah tidak ada dalil yang kuat yang menjadi dasar praktek tersebut. Lebih jauh ia juga menyarankan agar melihat tradisi khitan perempuan dari segi kemanfaatannya, baik dari segi kebersihan inaupun manfaat seksualnya. Bila ada manfaatyangdidapatkan dari praktek ini, ia mempersilahkan untuk melakukannya, tetapi sejauh pengetahuannya, khitan perempuan tidak berdampak apapun dalam kebersihan kelamin perempuan maupun meningkat kenikamatan seksual suami istri.

Dari uraian di atas, nampak jelas bahwa ada perubahan pemakanaan yang diberikan oleh masyarakat desa Pager terhadap tradisi khitan perempuan. Pada tahun 1960an khitan perempuan dimaknai sebagai religious identity sehingga menjadi praktek yang harus dijalani. Namun pada saat ini, pemaknaan yang diberikan masyarakat desa Pager berubah sehingga berbeda dengan pemaknaan yang diberikan para ulama dalam teks-teks fiqih. Mereka memaknai khitan perempuann sebagai tradisi Jawa yang terwarisi secara turun-temurun kecuali

Ulul Albab, Vol. 4 No. 1, 2003 
sebagian kalangan yang masih menganggapnya sebagai ajaran agama dan merupakan amalan sunnah.

\section{E. Faktor-faktor Penyebab Terjadinya Perbedaan antara Wacana Teks dan Wacana Konteks}

Pada awalnya, masyarakat desa Pager pernah melakukan praktek khitan perempuan, yaitu pada sekitar tahun 1960an. Dilihat dari prosedur yang digunakan, praktek ini hampir sama dengan anjuran yang ada dalam teks-teks fiqih dengan memotong atau melukai ujung klitoris. Di sisi lain tingkat keberagamaan mereka saat itu masih sangat awam, sehingga ada dugaan motivasi mereka lebih didasarkan pada taken for granted dari nenek moyang mereka dibandingkan dengan motif agama yang berasal dari kitab-kitab fiqih. Dan sebaliknya, pada saat ini, ketika tingkat keberagamaan mereka lebih baik, merekasudah tidak mempraktekkan khitan perempuan. Menurut sebagain besar dari mereka, khitan perempuan adalah tradisi warisan budaya Jawa yang tidak punya keterkaitan dengan hukum agama, sehingga tidak ada perasaan berdosa karena tidak mekakukannya. Padalah idealnya, sebagai masyarakat Muslim yang taat, mereka seharusnya mengikuti aturan hukum yang telah ditetapkan dalam teks-teks fiqih. Maka dari itu, penulis berkesimpulan bahwa perbedaan antara teks-teks fiqih dengan konteks masyarakat desa Pager pada saat ini disebabkan oleh beberapa faktor yang antara lain; perubahan sosial dan budaya masyarakat, perubahan pola pikir masyarakat, dan keawaman masyarakat terhadap teks-teks fiqih.

\section{Perubahan Sosial dan Budaya Masyarakat}

Perubahan sosial yang paling berpengaruh terhadap hilangnya tradisi khitan perempuan di desa Pager adalah perubahan dalam aspek kesehatan. Sebelum adanya program bidan masuk desa yang dicanangkan oleh pemerintah, proses pesalinan biasanya ditangani oleh duku bayi. Sebagaimana disebutkan di atas bahwa, para dukun bayi terkadang mengkhitan bayi perempuan yang baru dilahirkan walaupun hanya sekedar simbolik. Ketika pemerintah mecanangkan program bidan masuk desa, secara perlahan-lahan tradisi khitan perempuan mulai menghilang. 
Hal disebabkan para bidan tidak melayani praktek khitan perempuan karena dalam dunia medis, prosedur ini tidak dikenal.

Proses hilangnya tradisi khitan perempuan ini seakan mengalir dengan sendirinya tanpa adanya kesengajaan untuk menghilangkannya. Bidan yang sebenamya menjadi penyebab utama hilangnya tradisi ini pun tidak menyadari dan tidak membayangkan bahwa kehadirannya di desa Pager telah membantu aktifis feminis dalam "memerangi" tradisi khitan perempuan.

\section{Perubahan Pola Pikir Masyarakat}

Pada dasarnya perubahan pola pikir merupakan salah satu konsekwensi dari terjadinya perubahan sosial. Sebab perubahan sosial bisa mencakup hal-hal yang berifat kongkrit seperti bentuk bangunan rumah atau gaya berpakaian, mapun hal-hal yang bersifat abstrak seperti ide-ide dan pola pikir dalam masyarakat. Tetapi di sini perubahan pola pikir akan dibahas secara terpisah karena sejauh pengamatan penulis perubahan pola pikir memiliki peran yang signifikan dalam proses hilangnya tradisi khitan perempuan di desa Pager. Yang dimaksud dengan perubahan pola pikir di sini adalah perubahan pola pikir masyarakat dari pola pikir yang tidak rasional menjadi pola pikir yang rasional. Perubahan ini bisa dipengaruhi oleh beberasa hal, antara lain; ajaran agama, proses pendidikan dan pengaruh budaya luar.

Secara tidak langsung, agama memiliki peran dalam mengikis pemikiran yang tidak rasional. Kalaupun bukan sebagai peran yang paling berpengaruh dalam perubahan ini, tetapi minimal agama berfungsi sebagai pendorong terjadinya perubahan ini. ${ }^{13}$ Dakwah yang dilakukan para walisanga walaupun dilakukan secara akulturatif, tetapi memiliki dampak pada terkikisnya pola pikir yang tidak rasional. Pada dasarnya perubahan yang dilakukan para walisanga adalah untuk menghilangkan kepercayaan-kepercayaan dan mitologi-mitologi yang tidak sesuai dengan ajaran Islam. Namun demikian, perubahan itu secara tidak langsung mengajak masyarakat untuk menimbang atau memikirkan kembali ritual-ritual budaya Jawa tersebut apakah masuk akal atau tidak. Dan pada akhirnya masyarakat memiliki dua alternatif keputusan, melanjutkan ritual tersebut dengan mengubah substansinya agar sesuai dengan ajaran Islam atau meninggalkan ritual tersebut. 
Proses pendidikan juga merupakan faktor penentu dalam perubahan pola pikir masyarakat. Sementara ini pendidikan masih merupakan instrument yang paling jitu dalam merekayasa kehidupuan sosial. Setidaknya hal ini diakui oleh Alex Inkels ketika merumuskan manusia modern. Menurut Inkels, apabila kita mendidik masyarakat dengan pendidikan manusia modern, maka masyarakat itu secara beransur-ansur akan mengubah sistem atau struktrur sosialnya. Jadi rekayasa sosial dimulai dengan mengubah kepribadian individu yang terlibat dalam pranata sosial tersebut. Cara untuk mengubah kepribadian individu yang paling jitu adalah dengan menanamkan ide-ide modern melalui proses pendidikan. ${ }^{14}$

Secara statistik, jumlah penduduk desa Pager yang mengenyam bangku sekolah, apalagi perguruan tinggi, tidak begitu dominan. Mayoritas adalah hanya sampai pendidikan dasar dan pendidikan menengah. Walaupun hanya sampai pada tingkat pendidikan menengah, tetapi pola pikir mereka sudah berbeda dengan pola pikir masyarakat tradisional. Pola pikir mereka sudah lebih modern yang ditandai dengan lebih mengedepankan perhitungan rasional, seperti ketika dihadapkan kepada program keluarga berencana (KB). Mereka sudah tidak setuju lagi dengan pepata kuno "banyak anak banyak rejeki", tetapi mereka lebih setuju dengan program KB dengan pertimbangan bila jumlah anak direncanakan dengan baik maka masa depan mereka akan lebih terjamin.

Perubahan pola pikir masyarakat desa Pager juga dipengaruhi oleh adanya pengaruh dari luar. Pengaruh ini bisa melalui interaksi langsung dengan bertatap muka maupun secara tidak langsung dengan melaui media cetak dan elektronik. Ketika interaksi antara dua masyarakat berlangsung, biasanya terjadi proses pengaruh kebudayaan yang antara lain berbentuk difusi, akulturasi atau imitasi. ${ }^{15}$

Contoh kongkrit yang bisa ditemukan dalam kehidupan masyarakat desa Pager dari proses persentuhan budaya tersebut adalah proses medikalisasi, yakni proses penerimaan masyarakat terhadap penyembuhan secara medis. Sebelum ada bidan desa yang bertugas di Pager, sebagian dari mereka sudah ada yang melakukan persalinan dengan bantuan bidan di desa lain. Artinya, jauh hari sebelum ada bidan desa di Pager, masyarakatnya sudah mengenal dan menerima persalinan secara medis akibat pengaruh dari masyarakat luar. Ketika bidan desa masuk di Pager, masyarakat sudah memiliki pola pikir yang modern, yakni lebih memilih proses persalinan di bidan dari pada di dukun bayi.

Ulul Albab, Vol. 4 No. 1, 2003 
Semua pengaruh dari luar, bạik yang langsung maupun yang tidak langsung, berdampak pada asumsi mereka terhadap praktek khitan perempuan. Setelah sekian lama berinteraksi dengan masyarakat luar, masyarakat desa Pager mengetahui bahwa ternyata praktek khitan perempuan sudah tidak dilakukan di tempat lain. Dari sini, mereka berasumsi bahwa khitan perempuan ternyata memang hanya tradisi masyrakat Jawa yang tidak ada kaitannya dengan ajaran agama. Sebab di beberapa tempat sudah ditinggalkan dan tidak ada seorang kiai pun yang menganjurkan khitan bagi perempuan. Kondisi ini juga tidak terlepas dari ketidaktahuan mereka terhadap teks-teks fiqih yang sebenarnya menganjurkan umat Islam untuk melakukannya.

\section{Keawaman Masyarakat terhadap Teks-teks Fiqih}

Keawaman masyarakat desa Pager terhadap teks-teks fiqih khususnya yang berkenaan dengan hukum khitan perempuan tidak bisa diabaikan sebagai salah satu faktor penyebab leyapnya tradisi khitan perempuan di desa ini. Masyarakat desa Pager yang tergolong taat beribadah dan manyoritas bermazhab Syafi'iyah tidak mungkin meninggalkan anjuran agama yang terdapat dalam teks-teks fiqih apalagi tergolong perbuatan yang hukumnya wajib dan atau sunnah. Lebih-lebih dalam teks-teks fiqih tersebut pendapat ulama Syafi' iyah adalah yang paling tegas dibandingkan ulama mazhab lainnya, yaitu mayoritas ulamanya mewajibkan khitan perempuan dan minoritasnya menetapkan hukum sunnah.

Ketidaktahuan terhadap teks-teks fiqih tentang khitan perempuan tidak hanya dialami masyarakat biasa, tetapi juga para ustadz dan sebagian tokoh agama yang tidak mengetahui sejauh mana khitan perempuan dibahas dalam kitab fiqih.

“...kulo nate mireng nek sunat kangge tiang estri niku wonten malah nek mboten salah, pelaksanaanipun kedah dirahasiaaken. Anangeng kulo mboten sumerap wonten kitab punopo keterangan sunat tiang estri niku dijelasaken..."

( “...saya pernah mendengar kalau khitan perempuan itu ada malah kalau tidak salah, pelaksanaannya harus dirahasiakan. Tetapi saya tidak tahu dalam kitab apa khitan perempuan itu dijelaskan..."

Ulul Albab, Vol. 4 No. 1, 2003 
Dari uraian di atas dapat dipahami bahwa ternyata ajaran khitan perempuan yang terdapat dalam teks-teks fiqih tidak tersampaikan pada masyarakat bahkan pada kalangan yang sudah mengerti tetntang ajaran agama. Pertanyaannya, mengapa ajaran khitan perempuan tidak sampai pada mereka?

Ada dua asumsi yang bisa diajukan untuk menjawab bertanyaan di atas, pertama; karena pembahasan tentang khitan perempuan hanya ditemukan di beberapa kitab fiqih tingkat lanjut yang hanya dipelajari oleh santri yang sudah menguasai bahasa Arab.;Sehingga informasi tentang khitan perempuan dalal kitab fiqih tidak pernah tersentuh oleh masyarakat awam.

Kedua, karena ada anjuran dalam kitab-kitab fiqih untuk merahasiakan pelaksanaan khitan perempuan. Anjuran untuk merahasiakan pelaksanaan khitan perempuan ini menjadikan praktek ini jarang diperbincangkan di kalayak ramai bahkan bisa diangga tabu untuk membicarakannya. Ketertutupan dalam membincangkan masalah khitan perempuan menjadikannya tidak pernah disampaikan dalam majelis taklim dan tidak pernah dijadikan bahan ceramah dalam kegiatan keagamaan lainnya. Dan akibatnya, praktek yang dianggap sebagai ajaran agama dalam kitab-kitab fiqih ini tidak pernah tersampaikan ke masyarakat walaupun keberadaannya sebagai ajaran agama diakui oleh sebagain tokoh agama.

\section{E. Kesimpulan}

Dari uraian di atas dapat disimpulkan bahwa tidak semua kitab-kitab fiqih yang tersebar di masyarakat memuat penjelasan tentang khitan perempuan. Penjelasan tersebut hanya ditemukan dalam kitab-kitab fiqih tingkat lanjut yang jarang disentuh oleh masyarakat awam. Dalam kitab-kitab fiqih tersebut dinyatakan bahwa mayoritas ulama berpendapat khitan adalah ibadah yang wajib dilakukan oleh muslim laki-laki dan perempuan.

Sedangkan dalam konteks masyarakat desa Pager, khitan perempuan sudah tidak dijalani lagi walaupun masih ada sebagian orang yang menganggap khitan perempuan itu hukumnya wajib atau sunnah. Tidak dijalaninya perintah khitan perempuan oleh masyarakat desa Pager disebabkan adanya anggapan bahwa khitan perempuan adalah tradisi masyarakat zaman dulu yang tidak terkait dengan ajaran agama. Dari sini nampak jelas, bahwa pada saat ini terjadi perbedaan yang signifikan 
antara teks-teks fiqih dengan konteks masyarakat desa Pager dalam memaknai praktek khitan perempuan. Perbedaan tersebut disebabkan oleh tiga faktor, yaitu terjadinya perubahan sosial dan budaya masyarakat desa Pager, perubahan pola pikir masyarakat desa Pager, dan keawaman mereka terhadap teks-teks fiqih yang memuat penjelasan tentang hukum khitan perempuan.

\section{Endnotes}

1 Andree Feillard, et al.. Female Circumcision in Indonesia; to Islamize in Ceremony or Secrecy, dalam jurnal Archipel nomor 56, 1998 hal 357.

2 Ristiani Musyarofah, et al.. Khitan Perempuan antara Tradisi dan Ajaran Agama, (Pusat Studi Kependudukan dan Kebijakan Universitas Gadjah Mada, Yogyakarta. 2003)hal 89.

3 Basilica Dyah Putranti, et al.. Sunat Laki-laki dan Perempuan pada Masyarakat Jawa dan Madura, (Pusat Studi Kependudukan dan Kebijakan Universitas Gadjah Mada, Yogyakarta. 2003) hal.25

4 Bosworth C. E. etc (edt).. The Encyclopaedia of Islam (new edition), (vol.V, E.J. Brill. Leaden Netherland. 1986) hal. 20

5 . Saad Al Marshafi,. Khitan, (Gema Insani Press, Jakarta. 1996.) hal 13

6 Husein Muhammad,. Figh Perempuan, Refleksi Kiai atas Wacana Agama dan Gender. (LKiS, Yogyakarta. 2002) hal. 40

7 Bosworth C. E. etc (edt). Op.cit. hal 20

8 Andree Feillard, et al. Op.cit. hal 341

9 Muhammad bin Salim bin Said Babishil,. Is'âd al-Rafíq wa Bughyah al-Shadîq, (AlHaromain, Jeddah) hal.111

10 Muhammad Syatha Al-Dimyathi,. l'ânah Al-Thâlibîn, (Al-Ma'arif, Bandung, tanpa tahun.) hal. 173

"Lihat dalam Al-Syarbini, Muhammad al-Khatib. Mughni al-Muhtâj, (Dâr al-Fiqr, Bairut (tanpa tahun) hal. 203

12 Muhammad Syatha Al-Dimyathi, op.cit. hal 174

13 Ishomuddin.. Sosiologi Perspektif Islam (UMM Press, Malang. 1997) hal 154

14 Jalaluddin Rahmat, Rekayasa Sosial, Reformasi, Revolusi atau Manusia Besar? (Remaja Rosdakarya, Bandung. 2000) hal 122

is Ishomuddin, op.cit. hal 144-45

Ulul Albab, Vol. 4 No. 1, 2003 


\section{Bibliography}

Al-Dimyathi, Muhammad Syatha. (tanpa tahun). I'ânah Al-Thâlibîn, Al-Ma'arif, Bandung.

Al Marshafi, Saad. 1996. Khitan, Gema Insani Press, Jakarta.

Al-Syarbini, Muhammad al-Khatib. (tanpa tahun). Mughni al-Muhtâj, Dâr alFiqr, Bairut.

Al-Syarwani. (tanpa tahun). Hawâsyi, Dâr Ihya' al-Turats al-Arabi, Arab Saudi.

Babishil, Muhammad bin Salim bin Said.(tanpa tahun). Is 'âd al-Rafíq wa Bughyah al-Shadîq, Al-Haromain, Jeddah.

Bosworth C.E. etc (edt). 1986. The Encyclopaedia of Islam (new edition), vol.V, E.J. Brill. Leaden Netherland.

Feillard, Andree et al. 1998. Female Circumcision in Indonesia; to Islamize in Ceremony or Secrecy, Archipel 56, Paris.

Ishomuddin. 1997. Sosiologi Perspektif Islam 2 UMM Press, Malang.

Muhammad, Husein. 2002. Figh Perempuan, Refleksi Kiai atas Wacana Agama dan Gender. LKiS, Yogyakarta.

Musyarofah, Ristiani et al. 2003. Khitan Perempuan antara Tradisi dan Ajaran Agama, Pusat Studi Kependudukan dan Kebijakan Universitas Gadjah Mada, Yogyakarta.

Putranti, Basilica Dyah et al. 2003. Sunat Laki-laki dan Perempuan pada Masyarakat Jawa dan Madura, Pusat Studi Kependudukan dan Kebijakan Universitas Gadjah Mada, Yogyakarta.

Rahmat, Jalaluddin. 2000, Rekayasa Sosial, Reformasi, Revolusi atau Manusia Besar?Remaja Rosdakarya, Bandung. 